Buana Sains Vol 17 No 2: 189-196, 2017

\title{
EFEK PAPARAN ALGINAT DALAM PANGAN TERHADAP KADAR PROTEIN TOTAL, ALBUMIN DAN GLOBULIN DARAH
}

\author{
Pramono Sasongko dan Wahyu Mushollaeni
}

Fakultas Pertanian Universitas Tribhuwana Tunggadewi Malang

\begin{abstract}
Clinical analysis to determined the toxicity of new material could be done by biochemical analysis of wistar rat blood serum such as blood protein, albumin, and globulin content. In case of decreasing of those biochemical analysis indicated the reduction of liver function in metabolism process. Hence, this study were conducted in order to determined toxicity effect of alginate presence extracted from brown seaweed Turbinaria sp.due to the blood protein, albumin, and globulin content of wistar rat blood serum. The study were conducted by Complete Randomized Design (CRD) with alginate concentration treatment which were $0.5 \% ; 0.75 \% ; 1 \%$, and negative control. The results were shown that the treatment up to $1 \%$ of alginate concentration were not provide any toxicity effect in liver organ. These result was concluded due to the blood protein, albumin, and globulin content were presently still in a safe level.
\end{abstract}

Keywords: toxicity analysis, blood total protein, albumin, globulin, alginate

\section{Pendahuluan}

Pengujian sifat racun dan toksisitas suatu bahan untuk menghasilkan informasi yang dapat digunakan untuk menilai bahaya yang dapat timbul pada manusia dan lingkungan oleh pemaparan bahan tersebut dapat dilakukan dengan hewan uji atau tikus uji (Mirshafiey et al. 2005; Razavi et al. 2008). Zat toksik yang masuk kedalam tubuh akan didistribusikan ke seluruh tubuh atau ke organ tertentu sebagai sasaran utama ketoksikannya melalui peredaran darah. Organ utama sebagai sasaran zat toksik adalah hepar dan ginjal (Kanu et al., 2016). Pengujian toksisitas tersebut dapat berupa pengujian fisik hepar atau ginjal, pengujian biokimia, serta biokimia serum darah tikus wistar. Pengujian tersebut meliputi berat badan, pengujian fungsi hepar, serta pengujian beberapa parameter darah (Agbaje et al., 2009) diantaranya kadar protein total, albumin, dan globulin darah. Pengujian biokimia darah dapat memberikan infomasi mengenai kondisi fisik dan patologis kesehatan (Jorum et al., 2016). Hingga saat ini belum ada pengujian toksisitas alginat yang diekstraksi dari rumput laut coklat jenis Turbinaria sp. yang berasal dari pantai berkarang daerah Yogyakarta, sehingga penggunaannya dalam pangan atau sebagai bahan obat masih belum dapat dilakukan.

Turbinaria merupakan salah satu jenis rumput laut coklat yang berhabitat di pantai berkarang Daerah Wonosari Yogyakarta yang belum diketahui secara luas tentang pemanfaatannya, aspek toksisitas dan efek kesehatannya, walaupun telah berhasil diekstraksi dan diketahui komposisi kimianya. Standar alginat juga harus aman dikonsumsi (kode E). Oleh karena itu sangat diperlukan penelitian untuk mendapatkan data efek toksisitas paparan alginat yang 
diekstrak dari rumput laut coklat jenis Turbinaria sp. terhadap kadar protein total, albumin, dan globulin darah tikus wistar uji.

\section{Metode Penelitian}

\section{Bahan dan Peralatan Penelitian}

Bahan utama yang digunakan dalam penelitian yaitu alginat dan tikus wistar jantan sebagai obyek yang akan diteliti. Tikus wistar penelitian diperoleh secara consecutive random sampling, dengan kriteria inklusi yaitu tikus wistar, umur 2 bulan, berat badan 100-150 gram, kondisi sehat (aktif dan tidak cacat), dan kriteria eksklusi yaitu tikus mengalami sakit, bobot tikus menurun (kurang dari 100 gram), tikus mati dalam masa penelitian. Bahan pendukung meliputi alginat uji, bahan makanan dan minuman tikus wistar, serta bahan untuk pemeriksaan darah. Alginat diekstrak dari rumput laut coklat jenis Turbinaria sp. yang diperoleh dari pantai berkarang daerah Gunung Kidul Yogyakarta. Bahan-bahan kimia yang digunakan untuk ekstraksi alginat meliputi aquades, $\mathrm{CaCl}_{2} 1 \%$ dan $74 \%$, $\mathrm{HCl} 1 \%, \mathrm{HCl} 3 \%, \mathrm{HCl} 5 \%, \mathrm{HCl} 35 \%$, $\mathrm{KOH} 0,5 \%, \mathrm{KOH} 90 \%, \mathrm{Na}_{2} \mathrm{CO}_{3} 2,25 \%$, $\mathrm{Na}_{2} \mathrm{CO}_{3} \quad 10 \%, \quad \mathrm{Na}_{2} \mathrm{CO}_{3} \quad 95 \%, \quad \mathrm{NaOCl}$ $10 \%, \mathrm{NaOCl} 12 \%$, dan isopropilalkohol $95 \%$.

Peralatan yang digunakan meliputi kandang untuk hewan coba, alat untuk terminasi tikus di akhir perlakuan, spektrofotometer, sentrifuge untuk memisahkan serum, tabung sentrifuge, tabung cuvet, serta blender untuk menghaluskan ekstrak rumput laut coklat.

\section{Pelaksanaan Penelitian}

Alginat yang akan diujikan, diaplikasikan dalam bentuk bakso ikan tengiri sebagai pakan tikus uji, yang akan diberikan secara oral setiap hari selama 90 hari.
Konsentrasi alginat dalam bakso ikan tengiri adalah $0,5 \%$ (1); $0,75 \%$ (2) dan $1 \%$ (3). Perlakuan kontrol (K) dikenakan dengan perlakuan kontrol negatif, yaitu pemberian pakan bakso ikan tengiri tanpa pemberian alginat. Tikus uji sebanyak 20 ekor, masing-masing perlakuan 5 ekor tikus. Whistar yang digunakan adalah berusia 4 bulan dan mempunyai berat antara 100-150 g.

Penelitian ini dilakukan dalam 4 tahap yaitu ekstraksi alginat dari jenis rumput laut coklat Turbinaria sp., pembuatan bakso ikan tengiri, uji toksisitas dan analisa data. Rancangan yang digunakan adalah Rancangan Acak Lengkap, yaitu $\mathrm{K}, \mathrm{TB}_{1}, \mathrm{~TB}_{2}$ dan $\mathrm{TB}_{3}$. Analisa darah dilakukan 2 kali yaitu awal (pretest) dan akhir (post test). Pre dan post test dilakukan untuk menganalisa kadar biokimia darah yaitu protein total, albumin, dan globulin. Ransum perlakuan diberikan secara ad libitum, selama 90 hari. Pada akhir masa percobaan, tikus dibedah untuk dilakukan pengambilan darah. Tikus yang telah dibius dengan dietil eter, dibedah untuk diambil darahnya melalui jantung sebanyak $\pm 8 \mathrm{ml}$ dengan menggunakan jarum suntik spuit $10 \mathrm{ml}$. Darah yang diperoleh disentrifuse untuk mendapatkan serumnya. Analisa data menggunakan SPSS 16.00. Uji hipotesis menggunakan uji parametrik One $W$ ay Anova. Ditetapkan true confidences uji ini adalah 95\%.

\section{Hasil dan Pembahasan}

\section{Pengaruh Pemberian Diet Alginat terhadap Kadar Total Protein Serum Darah}

Berdasarkan hasil penelitian terhadap kadar total protein serum, albumin, dan globulin menunjukkan bahwa dengan pemberian diet alginat Turbinaria hingga 
P. Sasongko dan W. Mushollaeni /Buana Sains Vol 17 No 2 : 189-196

konsentrasi $1 \%$ tidak memberikan efek yang nyata terhadap penurunan ketiga parameter biokimia darah tikus wistar di akhir penelitian. Dibandingkan dengan kontrol yang tidak diberikan asupan diet alginat, kadar protein serum cenderung mengalami peningkatan hingga diet alginat sebanyak $0,75 \%$. Diet alginat sebanyak $1 \%$ memberikan pengaruh penurunan kadar total protein serum. Kadar total protein serum tikus wistar yang diberi diet alginat diakhir perlakuan berada pada kisaran 7,048-7,792 g/dl. Kadar ini telah memenuhi standar normal kadar total protein dalam serum darah tikus wistar sesuai dengan Sammad et al. (2017) yaitu 6-8 g/dl.
Adanya peningkatan kadar protein mengindikasikan bahwa diet alginat yang ditambahkan dalam pakan tidak memberikan pengaruh yang nyata terhadap kondisi biokimia dan fisiologis tubuh tikus wistar, serta tidak berefek toksik. Sebelum perlakuan, tidak ada perbedaan bermakna berat badan tikus dikarenakan sampel homogen. Keseluruhan tikus wistar baik kontrol maupun tikus wistar yang diberikan pakan mengandung alginat, berada dalam kondisi baik dan tidak terdapat kasus kematian. Tingkah laku semua tikus pada kontrol dan keempat perlakuan terlihat sehat, aktif dan tidak ada tanda-tanda keracunan.

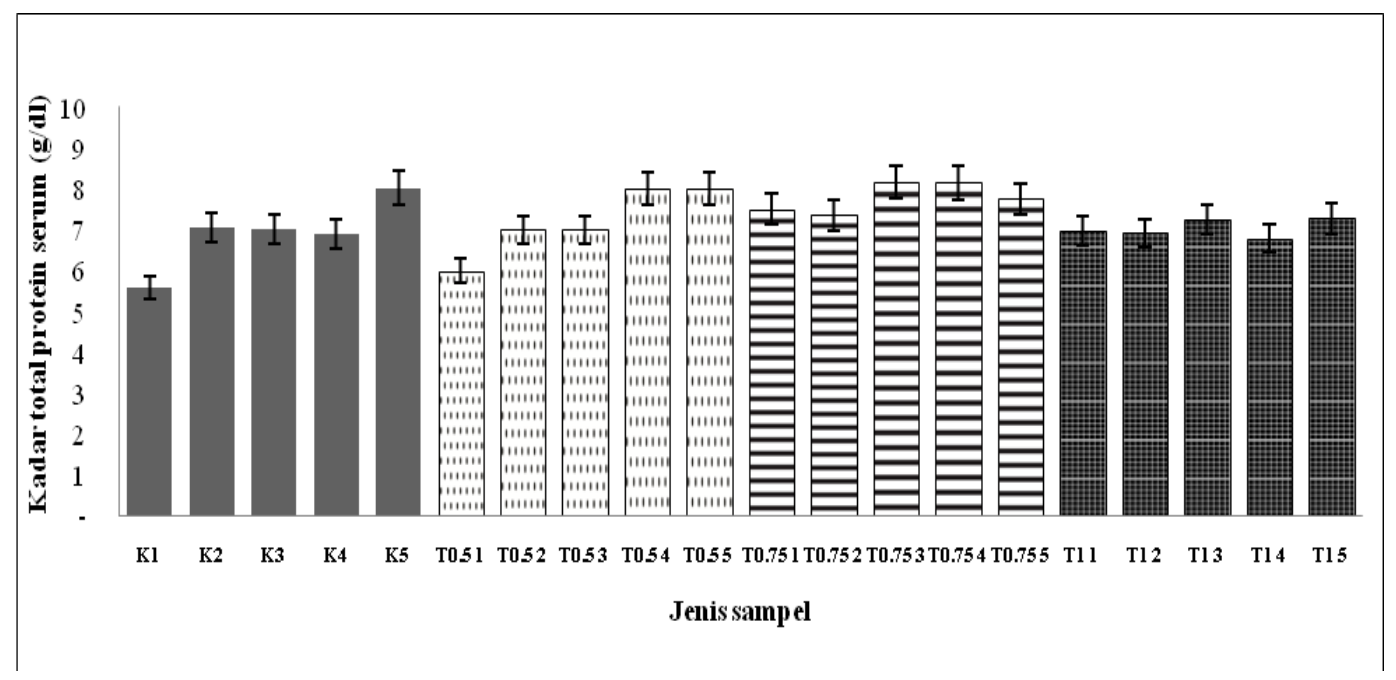

Gambar 1. Profil kadar total protein serum (g/dl) darah tikus wistar dengan diet alginat Turbinaria sp. K: kontrol; T: Alginat dari jenis Turbinaria sp.; Konsentrasi penambahan alginat dalam pakan : $0,5 \% ; 0,75 \% ; 1 \%$.

Keseluruhan tikus wistar dengan pakan yang mengandung diet alginat, tidak menunjukkan pengaruh terhadap berat badannya. Jika pemberian berulang suatu zat tertentu dengan dosis tertinggi atau maksimal dan tidak menunjukkan tandatanda toksik atau abnormalitas, maka dapat dikatakan zat tersebut aman untuk penggunaan jangka panjang. Tidak terdapat penurunan berat badan pada seluruh tikus wistar yang diberikan pakan mengandung alginat. Namun justru mengalami peningkatan berat badan, dengan rerata peningkatan 49-60 gram. Hal ini menunjukkan bahwa pemberian diet alginat tidak berpengaruh pada proses metabolisme protein dalam tubuh tikus dan sebaliknya dengan asupan alginat yang juga mengandung protein, telah dapat dimetabolisme menjadi asam 
amino yang juga akan masuk kedalam serum dan mengindikasikan juga meningkatnya metabolisme protein (Aprilia, 2012).

\section{Pengaruh Pemberian Diet Alginat terhadap Kadar Albumin Serum Darah}

Kadar albumin serum darah tikus wistar diakhir perlakuan antara 2,298-2,536 $\mathrm{g} / \mathrm{dl}$, sedangkan kadarnya pada kondisi kontrol adalah 2,354 g/dl. Semakin meningkatkanya persentase alginat yang ditambahkan dalam pakan, akan meningkatkan kadar albumin serum. Namun kondisi ini menurun setelah penambahan 1\% alginat dalam ransum (Gambar 2). Penurunan atau peningkatan yang terjadi tidak bersifat nyata, baik dari hasil perhitungan ANOVA maupun jika dilihat dari hasil analisa laboratorium dan perkembangan secara fisiologis tikus wistar. Adanya kondisi kadar albumin yang meningkat atau menurun dipengaruhi oleh masukan protein kedalam tubuh, kondisi pencernaan atau absorpsi protein yang baik atau terganggu, serta adanya gangguan penyakit. Namun demikian, hasil penelitian tersebut dapat membuktikan bahwa dengan penambahan alginat hingga $0,75 \%$ tidak memberikan efek yang nyata pada kemungkinan terjadinya kerusakan sel-sel hepar. Hal ini berhubungan antara sintesis albumin dan hepar. Sutedjo (2007) menyatakan bahwa albumin yang disintesa di hepar berfungsi untuk mempertahankan tekanan osmotik darah dan mempertahankan cairan yang ada dalam sistem vaskular, sehingga jika terdapat kerusakan sel hepar maka akan berakibat pada penurunan sintesa albumin.

Sel hepar merupakan jaringan utama yang menjadi tujuan utama dari pengaruh radikal bebas karena hepar merupakan tempat terjadinya proses metabolisme senyawa xenobiotik. Kadar albumin serum tikus wistar setelah diberikan perlakuan menunjukkan kadar yang lebih rendah dibandingkan dengan kadar normalnya yaitu 3,40-4,8 g/dl, namun kadar albumin diakhir perlakuan masih dalam rentang albumin kontrol. Pengujian terhadap biokimia serum darah dan untuk mengetahui adanya kemungkinan kerusakan sel hepar karena pengaruh toksik, maka dilakukan pengujian terhadap kadar total protein dan albumin serum melalui pengukuran jumlah poliribosom RE (Retikulum Endoplasma) sintesa protein plasma (Sammad et al., 2017). Dua komponen penting yang disintesa dalam poliribosom dalam membran adalah protein dan albumin. Protein yang terdapat dalam plasma tersebut akan melintasi jalur utama sekresi dalam sel yaitu dari antar membran endoplasma, masuk ke badan golgi, diedarkan, dan disimpan hingga ke plasma sel. Cadangan protein ini akan disintesa awal sebagai preprotein (Murray et al., 2003).

Tidak tampaknya adanya penurunan dan disfungsi fisiologis selama pemeliharaan tikus wistar dengan diet alginat menunjukkan bahwa tidak adanya efek toksik yang nyata pada organ hepar, serta dimungkinkan adanya kandungan antioksidan yang terdapat dalam alginat, sehingga dapat melindungi organ. Diet menggunakan rumput laut yang didalamnya mengandung antioksidan, berdampak pada pengurangan terbentuknya radikal bebas serta dapat membantu melindungi sel dari kerusakan akibat paparan radikal bebas (Crandall, 2007; Dianitami, 2009; Gitawati, 1995; Schroder et al, 1991; Suptijah, 2009; Wibowo, 2009). Menurut Wikanta et al. (2008), sistem pertahanan tubuh yang berupa sistem kontrol enzim antioksidan bekerja mengatur reaksi pembentukan radikal bebas yang 
diperlukan dan menetralkan kelebihan radikal bebas yang terbentuk akibat dari asupan makanan yang dapat merusak jaringan di dalam tubuh.

Mushollaeni et al. (2014) menyatakan bahwa pada kondisi terbentuknya radikal bebas ini, terjadi peningkatan kadar hidrogen peroksida dan superoksida. Diet menggunakan rumput laut yang didalamnya mengandung antioksidan, berdampak pada pengurangan terbentuknya radikal bebas karena dapat dikurangi efek radikal bebas ini dengan diet produk yang berfungsi sebagai penangkap radikal hidroksil. Selanjutnya Wikanta et al. (2008) menyatakan bahwa alga coklat mengandung senyawa kimia klorofil-a dan -c, $\beta$-karoten, violasantin dan fukosantin, pirenoid dan filakoid, laminarin, selulosa, dan algin. Pigmen karoten diketahui memiliki sifat antioksidan sehingga mampu bertindak sebagai antioksidan dan penangkal radikal bebas hasil proses metabolisme dalam tubuh.

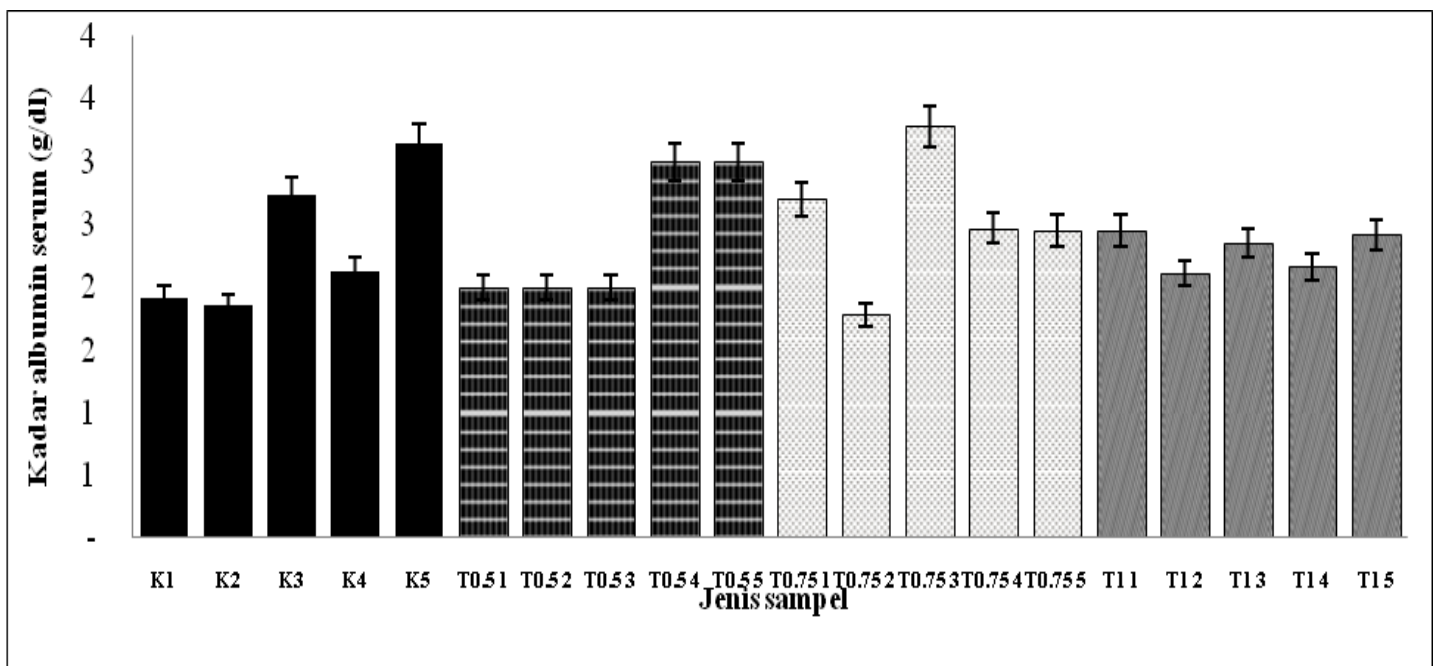

Gambar 2. Profil kadar albumin serum (g/dl) darah tikus wistar dengan diet alginat Turbinaria sp. K: kontrol; T: Alginat dari jenis Turbinaria sp.; Konsentrasi penambahan alginat dalam pakan : $0,5 \% ; 0,75 \% ; 1 \%$.

\section{Pengaruh Pemberian Diet Alginat terhadap Kadar Globulin Serum Darah}

Kadar globulin rata-rata serum darah akhir penelitian dari tikus wistar yang diberi perlakuan diet alginat $0,75 \%>$ $0,5 \%>1 \%(5,256 \mathrm{mg} / \mathrm{dl}>4,800 \mathrm{mg} / \mathrm{dl}$ $>4,750 \mathrm{mg} / \mathrm{dl})$. Kadar globulin serum tersebut lebih tinggi dibandingkan kadar normal pada serum tikus kontrol yaitu 4,564 mg/dl (Gambar 3). Kadar globulin setelah perlakuan tersebut menunjukkan bahwa kondisi tikus wistar selama pemaparan dengan diet yang mengandung alginat, tidak terpengaruh dan proses metabolisme berlangsung dengan baik, namun pada saat penambahan alginat $1 \%$ sudah mulai tampak adanya gangguan yang ditunjukkan dengan penurunan kadar. Penurunan kadar globulin yang terjadi tidak menunjukkan perubahan secara nhyata terhadap perilaku makan dan fisiologis lainnya dari tikus uji. 
Keberadaan globulin dalam protein dalam plasma menjadi penting karena merupakan bagian dari protein total dalam plasma dan juga menjadi salah satu indikator ketidakseimbangan total kandungan protein dalam tubuh. Pada kondisi tubuh terpapar suatu zat toksik, sistem imun tubuh akan melawan infeksi termasuk dengan hepar (Kemasari et al., 2012). Mekanisme ini akan mengakibatkan terjadinya kerusakan pada sel-sel hepar dan akhirnya akan menurunkan fungsi hepar dalam sintesa protein. Albumin (Murray et al., 2003) dan globulin yang merupakan bagian dari protein juga akan menurun kadarnya.

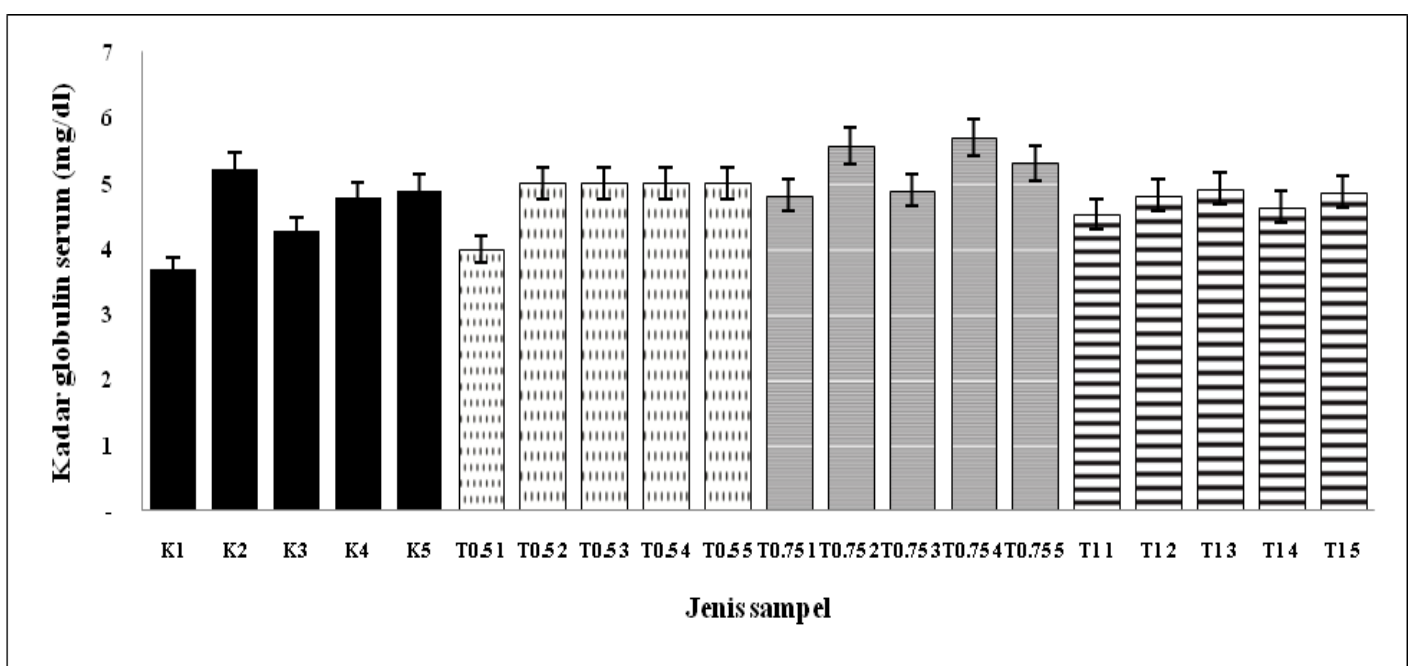

Gambar 3. Profil kadar globulin serum (g/dl) darah tikus wistar dengan diet alginat Turbinaria sp. K: kontrol; T: Alginat dari jenis Turbinaria sp.; Konsentrasi penambahan alginat dalam pakan : $0,5 \% ; 0,75 \% ; 1 \%$.

\section{Kesimpulan}

Berdasarkan hasil penelitian dapat disimpulkan bahwa penggunaan alginat dalam batas $1 \%$ tidak memberikan pengaruh yang nyata terhadap terjadinya toksis pada organ hati dengan indikator kadar albumin dan globulin darah yang masih dalam batas aman, serta tidak mengakibatkan penurunan kadar protein total dibawah batas aman.

\section{Ucapan Terimakasih}

Terimakasih disampaikan kepada Kopertis Wilayah VII Jawa Timur, Kementerian Pendidikan dan Kebudayaan tahun 2014 atas pendanaan Penelitian Dosen Muda.

\section{Daftar Pustaka}

Agbaje, E. O., Adeneye, A. A., and Daramola, A. O. 2009. Biochemical and toxicological studies of aqueous extract of Syrigium aromaticum (L.) Merr. \& Perry (Myrtaceae) in rodents. African Journal of Traditional, Complementary, and Alternative Medicines 6(3): 241 254.

Aprilia, R. P., Pramana, A. W. M. and Oktavianie, D. A. A. P. 2012. Specificity and sensitivity of thyroglobulin and serum protein profile of autoimmune thyroiditis model rat (Rattus norvegicus) induced by sodium iodide. Diakses: July 5, 2017. 
https://fkh.ub.ac.id/wp-

content/uploads/2012/10/10.-

Risky-Pamwindya.pdf.

Crandall, J. P. 2007. Diabetus mellitus (DM). Available from: http://www.merck.

/mmpe/sec12/ch158/ch158b.h tml

Dianitami, R. 2009. Efek Rumput Laut Eucheuma sp. terhadap Kadar Glukosa Darah dan Jumlah Trombosit Tikus Wistar yang Diinduksi Aloksan. [cited 2013 August 05]. Available from: http:/ / eprints.undip.ac.id/7761 $/ 1 /$ ratna_dia nitami.pdf

Giknis, M. and Clifford, C. 2008. Clinical laboratory parameters for Crl:WI (Han). Charles River. 1$18 \mathrm{p}$.

Gitawati, R. 1995. Radikal Bebas - Sifat dan Peran dalam Menimbulkan Kerusakan/Kematian Sel. Cermin Dunia Kedokteran, 102 $: 33$.

Jorum, O. H., Piero, N. M. and Machocho, A. K. 2016. Haematological effects of dichloromethane-methanolic leaf extracts of Carissa edulis (Forssk.) vahl in normal rat models. Journal Hematology \& Thromboembolic Diseases 4(1): 2-8.

Kanu, K. C., Solomon, N. I. and Atiata, O. 2016. Haematological, biochemical and antioxidant changes in wistar rats exposed to dichlorvos based insecticide formulation used in Southeast Nigeria. Toxics 4(28): 2-8.

Kemasari, P., Sangeetha S, and Venkatalakshmi P. Antihyperglycemic activity of Mangifera indica Linn. in alloxan induced diabetic rats. J
Chem Pharm Res.

2011;3(5):653-9.

Mirshafiey, A., Cuzzocrea, S., Rehm, B., Mazzon, E., Saadat, F. and Sotoude, M. 2005. Sodium Alginate as A Novel Therapeutic Option in Experimental Colitis . Scand J Immunol $61: 435-441$

Murray, K., Graner, D., Mayes, P. dan Rodwel, V. 2003. Biokimia. Harper. Edisi 25. EGC. Jakarta. 1734-1748 pp.

Mushollaeni, W., Supartini, N. and Sriwaningsih, E. R. 2014. Toxicity Test of Alginate from Sargassum and Padina on the Liver of Mice. Food and Public Health 4(4): 204-208.

Razavi, A., Khodadadi, A., Eslami, M. B., Eshraghi, S. and Mirshafiey, A. 2008. Therapeutic Effect of Sodium Alginate in Experimental Chronic Ulcerative Colitis . Iran J Allergy Asthma Immunol 7: 13 $-18$.

Sammad, F. H. A., Athiro, N. A. S. and Santoso, H. 2017. Injection of Scurrula atropurpurea (Bl) Dans metanolic extract in sub-chronic to total protein and albumin of female mice. Bioscience-Tropic 2(2): 49-54.

Schroder, S., Palinski, W. and SchmidSchonbein, G. W. 1991. Activated Monocytes and Granulocytes, Capillary Nonperfusion, and Neovascularization in Diabetic Retinopathy. American Journal of Pathology, 1991 July; 139(1) : $81-100$.

Smith, J. B. dan Mangkoewudjojo. 1998. Pemeliharaan, pembiakan dan penggunaan hewan coba di daerah tropis. 
P. Sasongko dan W. Mushollaeni /Buana Sains Vol 17 No 2 : 189-196

Suptijah, P. 2009. Rumput Laut:

Prospek dan Tantangannya.

[cited 2013 August 06].

Available from:

http://tumoutou.net/702_04

212/pipih_suptijah.htm

Sutedjo, S. K. M. 2007. Mengenal penyakit melalui hasil pemeriksaan laboratorium. Amara Books. Yogyakarta.

Wibowo, T. A. A. 2009. Efek Diet Rumput Laut Eucheuma sp. terhadap Jumlah Monosit Tikus Wistar yang disuntik Aloksan. [cited 2013 August 05]. Available from: http://eprints.undip.ac.id/77 68/

Wikanta, T., Damayanti, R. dan Rahayu, L. 2008. Pengaruh Pemberian K-Karagenan dan 'I-Karagenan terhadap Penurunan Kadar Glukosa Darah Tikus Hiperglikemia. Jurnal Pascapanen dan Bioteknologi Kelautan dan Perikanan. 3(2): 131-138. 